\title{
RESEARCH
}

Open Access

\section{Clinical and imaging outcomes after intrathecal injection of umbilical cord tissue mesenchymal stem cells in cerebral palsy: a randomized double-blind sham-controlled clinical trial}

Man Amanat ${ }^{1}$, Anahita Majmaa ${ }^{2}$, Morteza Zarrabi ${ }^{3}$, Masoumeh Nouri ${ }^{3}$, Masood Ghahvechi Akbari², Ali Reza Moaiedi', Omid Ghaemi ${ }^{5}$, Fatemeh Zamani ${ }^{5}$, Sharif Najafi ${ }^{6}$, Reza Shervin Badv ${ }^{2}$, Massoud Vosough ${ }^{3}$, Amir Ali Hamidieh ${ }^{7}$, Mona Salehi ${ }^{8}$, Hadi Montazerlotfelahi ${ }^{9}$, Ali Reza Tavasoli ${ }^{2}$, Morteza Heidari ${ }^{2}$, Hossein Mohebi ${ }^{10}$, Ali Fatemi ${ }^{11,12}$, Amir Garakani ${ }^{13,14}$ and Mahmoud Reza Ashrafi ${ }^{2 *}$ (1)

\begin{abstract}
Background: This study assessed the safety and efficacy of intrathecal injection of umbilical cord tissue mesenchymal stem cells (UCT-MSC) in individuals with cerebral palsy (CP). The diffusion tensor imaging (DTI) was performed to evaluate the alterations in white-matter integrity.

Methods: Participants (4-14 years old) with spastic CP were assigned in 1:1 ratio to receive either UCT-MSC or sham procedure. Single-dose $\left(2 \times 10^{7}\right)$ cells were administered in the experimental group. Small needle pricks to the lower back were performed in the sham-control arm. All individuals were sedated to prevent awareness. The primary endpoints were the mean changes in gross motor function measure (GMFM)-66 from baseline to 12 months after procedures. The mean changes in the modified Ashworth scale (MAS), pediatric evaluation of disability inventory (PEDI), and CP quality of life (CP-QOL) were also assessed. Secondary endpoints were the mean changes in fractional anisotropy (FA) and mean diffusivity (MD) of corticospinal tract (CST) and posterior thalamic radiation (PTR).
\end{abstract}

\footnotetext{
* Correspondence: ashrafim@tums.ac.ir

${ }^{2}$ Pediatrics Center of Excellence, Department of Pediatric Neurology,

Children's Medical Center, Growth and Development Research Center,

Tehran University of Medical Sciences, Tehran, Iran

Full list of author information is available at the end of the article
}

C C The Author(s). 2021 Open Access This article is licensed under a Creative Commons Attribution 4.0 International License, which permits use, sharing, adaptation, distribution and reproduction in any medium or format, as long as you give appropriate credit to the original author(s) and the source, provide a link to the Creative Commons licence, and indicate if changes were made. The images or other third party material in this article are included in the article's Creative Commons licence, unless indicated otherwise in a credit line to the material. If material is not included in the article's Creative Commons licence and your intended use is not permitted by statutory regulation or exceeds the permitted use, you will need to obtain permission directly from the copyright holder. To view a copy of this licence, visit http://creativecommons.org/licenses/by/4.0/ The Creative Commons Public Domain Dedication waiver (http://creativecommons.org/publicdomain/zero/1.0/) applies to the data made available in this article, unless otherwise stated in a credit line to the data. 
Results: There were 36 participants in each group. The mean GMFM-66 scores after 12 months of intervention were significantly higher in the UCT-MSC group compared to baseline $(10.65 ; 95 \% \mathrm{Cl} 5.39,15.91)$ and control $(\beta 8.07 ; 95 \% \mathrm{Cl}$ $1.62,14.52$; Cohen's $d$ 0.92). The increase was also seen in total PEDI scores (vs baseline 8.53 ; $95 \% \mathrm{Cl} 4.98,12.08$; vs control: $\beta 6.87 ; 95 \% \mathrm{Cl} 1.52,12.21$; Cohen's $d 0.70)$. The mean change in MAS scores after 12 months of cell injection reduced compared to baseline $(-1.0 ; 95 \% \mathrm{Cl}-1.31,-0.69)$ and control $(\beta-0.72 ; 95 \% \mathrm{Cl}-1.18,-0.26$; Cohen's $d 0.76)$. Regarding CP-QoL, mean changes in domains including friends and family, participation in activities, and communication were higher than the control group with a large effect size. The DTI analysis in the experimental group showed that mean FA increased (CST 0.032; 95\% Cl 0.02, 0.03. PTR $0.024 ; 95 \% \mathrm{Cl} 0.020,0.028$ ) and MD decreased (CST $-0.035 \times 10^{-3} ; 95 \% \mathrm{Cl}-0.04 \times 10^{-3},-0.02 \times 10^{-3}$. PTR $-0.045 \times 10^{-3} ; 95 \% \mathrm{Cl}-0.05 \times 10^{-3},-0.03 \times 10^{-3}$ ); compared to baseline. The mean changes were significantly higher than the control group.

Conclusions: The UCT-MSC transplantation was safe and may improve the clinical and imaging outcomes.

Trial registration: The study was registered with ClinicalTrials.gov (NCT03795974).

Keywords: Cerebral palsy, Stem cell, Diffusion tensor imaging, Gross motor function, Children

\section{Introduction}

Stem cells are defined as pluripotent cells with the ability of self-renewal and the capacity of differentiation into the other cell types. There has been greater interest in the use of stem cell therapy in recent years; especially for the treatment of neurological disorders [1]. The central nervous system (CNS) is unable to regenerate new cells and damages to CNS can be permanent. Several studies assessed the safety and efficacy of different stem cells in the treatment of individuals diagnosed with stroke [2], multiple sclerosis [3], Parkinson's disease [4], Huntington's disease [5], and spinal cord injury [6]. To date, many aspects of cell-based therapy remained unknown. The optimal dose, the most appropriate type of cell, and the best route of cell administration should be identified to provide safe and effective protocols without raising ethical concerns. Different underlying mechanisms of action have been described to justify the potential efficacy of stem cell therapy. Regarding mesenchymal stem cells (MSCs), it is believed that paracrine signaling and immunomodulation have the most critical effects. These cells can release neurotrophic factors, anti-oxidant molecules, angiogenic, anti-inflammatory, anti-fibrotic, and anti-apoptotic agents that enhance tissue repair after injury $[7,8]$. The capacity of MSCs to regenerate and differentiate to new cells is another proposed mechanism [9] but studies reported its limited efficacy and showed that migration of cells to the site of injury is not necessary [7]. It is now clear that the mechanism of action for many stem cells is not a consequence of differentiation [10].

The umbilical cord derives from the yolk sac and contains two arteries, one vein, and a gelatinous substance composed of sulfated proteoglycans with collagenous fibers; known as Wharton's jelly [11]. The umbilical cord was found to have great proportions of stem cells. The first successful stem cell transplant was from umbilical cord blood cells on a 6-year-old-boy with Fanconi anemia in 1988 [12]. Low immunogenicity, low risk of graft versus host disease, and ease of cell collection are major advantages of using cells derived from the umbilical cords [11]. Umbilical cord tissue mesenchymal stem cell (UCT-MSC) has been used in recent studies to determine their safety and clinical efficacy [13-15].

Cerebral palsy (CP) is the leading cause of physical disability in children and is known as a group of nonprogressive permanent CNS disorders that affected movements, muscle tone, and coordination [16]. The global prevalence of $\mathrm{CP}$ was estimated to be up to 3 per 1000 individuals [17]. Preclinical studies reported that some types of stem cells (e.g., MSC) had neuroprotective effects on animal models of neonatal hypoxia-ischemia [18-20]. Few randomized trials demonstrated the promising clinical effects of stem cell therapy in children with CP (reviewed in [21-23]). We conducted this randomized double-blind sham-controlled trial to assess the safety and clinical effects of intrathecal injection of UCT-MSC in CP. To assess the impact of cell therapy on the alteration of white matter integrity, we performed quantitative diffusion tensor imaging (DTI) before and after treatment. DTI is a non-invasive imaging method that can characterize the micro-structural changes in white matter tracts based on the diffusion of water molecules. We hypothesized that the UCT-MSC could significantly improve clinical and imaging outcomes compared to the control group (superiority trial).

\section{Methods}

\section{Study design}

This multi-center, population-based randomized doubleblind sham-controlled trial with single intrathecal stem cell injection was conducted in Children's Medical Center and Imam Reza hospital in Tehran province and Bandar Abbas pediatric hospital in Bandar Abbas province, 
Iran. The study was divided into four phases: [1] initial screening phase, [2] baseline phase, [3] double-blind treatment phase, and [4] follow-up phase.

\section{Inclusion and exclusion criteria}

Males and females aged 4 to 14 years old who were diagnosed with spastic $\mathrm{CP}$ according to standard criteria [16], gross motor function classification system (GMFCS) level 2-5, and white matter lesions in brain magnetic resonance imaging (MRI) (e.g., periventricular leukomalacia) were included in the study. Individuals with other types of $\mathrm{CP}$ (e.g., athetoid, ataxic, or mixed $\mathrm{CP}$ ), co-morbid neurological disorders (e.g., untreated epilepsy), or congenital infections (TORCH Syndrome) were excluded. Severe anemia (hemoglobins $<8 \mathrm{mg} / \mathrm{dl}$ ), coagulation disorders, history of malignancy, prior cell infusion, renal insufficiency, and liver failure were other exclusion criteria.

The ethics committee of Tehran University of Medical Sciences approved the final methods (Number: IR.TUMS.VCRREC.1996.2506). Parents of participants had access to all information of the trial and a printed protocol of the study was given to them. They were informed that participation was optional, and withdrawal was possible whenever they asked for. Written informed consent was achieved from parents before the initiation of any study procedures. We also explained the protocol to children and assent was obtained. The study was registered with ClinicalTrials.gov (NCT03795974) and Iranian registry of clinical trials; irct.ir (IRCT201706176907N13).

\section{Rehabilitation therapy}

All individuals were under rehabilitations during the study. One approach and technique of rehabilitation was established and conducted for included participants to reduce confounders. The Bobath concept was used in this study that aimed to affect muscle tone and improve the postural alignment by specific handling techniques $[24,25]$. Each session lasted for $75 \mathrm{~min}$ and participants attended three times per week for rehabilitation during the study.

\section{Randomization and blinding}

All included participants were randomly assigned in 1:1 ratio using permuted block randomization via interactive web response system to receive either UCT-MSC or sham procedure, respectively. The responsible statistician was masked to the clinical data of cases. Personnel staff responsible for cell preparations was not masked, but they had no contacts with participants, parents, or investigators. They also had no information about the clinical and imaging characteristics of patients. All participants, their parents, and investigators were blinded during the study unless serious adverse events occurred that emergent evaluations and treatments by medical staff were essential. A small needle prick to the lower back was performed as a sham procedure. All individuals were sedated to prevent awareness and to reduce spasticity during the procedure.

\section{Procedures \\ Initial screening and baseline phases}

Physical and neurological examinations were performed on children and adolescents with CP. GMFCS was used for initial functional assessment and brain MRI was also performed. Screening tests included blood count (e.g., hemoglobin, white blood cells, and platelets), serum chemistry (e.g., liver function test, creatinine, and urea), prothrombin time, partial thromboplastin time, and electro-encephalography (EEG) (phase 1). Gross motor function measure (GMFM)-66, modified Ashworth scale (MAS), pediatric evaluation of disability inventory (PEDI), and CP quality of life (CP-QoL) were used to evaluate the baseline clinical characteristics of eligible participants. Diffusion tensor imaging (DTI) was also performed to track white matter abnormalities in motor fibers (phase 2).

\section{Motor function assessment}

GMFCS is a 5-level clinical classification system to describe the motor function of people with CP $[26,27]$. The distinctions between levels are based on functional abilities (Supplement 1). A prior study reported excellent reliability of GMFCS for children aged 2 to 12 years old with CP (kappa: 0.75) [26]. The GMFM-88 was developed to measure changes in gross motor function over time or with treatment in people with CP [28]. The GMFM-66 was found through Rasch analysis to best describe the gross motor function of children with $\mathrm{CP}$ of varying abilities and is a 66 item subset of the original 88 items [29]. It has a unidimensional scale providing interval scaling rather than the ordinal scaling of the GMFM-88. It was shown that inter-rater reliability of Farsi version of this scale for all dimensions was between 0.97 and 0.99 and the intra-rater reliability was 0.99 [30]. Cronbach's alpha coefficient for all dimensions was between 0.78 and 0.94 [30].

\section{Spasticity assessment}

The MAS can be determined according to the examination of muscle tone [31] (Supplement 2). The scores are measured based on the level of resistance during the passive movement of the antagonist muscles. The elbow flexor, wrist flexor, knee extensor, hip adductor, and ankle plantar flexor were examined on the spastic side(s), and the mean MAS score was recorded in each individual. Participants were in sitting position to examine hip adductor and supine position to test other muscles. The interpretation of MAS should be with extreme 
caution. Several limitations to MAS were described previously [32]. Low inter- and intra-rater reliability of MAS in children with CP were estimated [33, 34], and the validity of the scale was poor [35]. The scale, however, quantify muscle tone in ordinal numbers and can be easily used in clinical settings.

\section{Disability assessment}

PEDI was developed to assess the performances of children with disabilities in 3 dimensions including self-care, mobility, and social function. The Farsi version of PEDI in children with $\mathrm{CP}$ was reported to have high internal consistency (Cronbach's alpha 0.94 to 0.98 ). The results of test-retest reliability were excellent in self-care (0.99) and social performance [1], and good in mobility dimension (0.66) [36].

\section{Quality of life assessment}

CP-QoL was designed to evaluate the well-being across different domains of life in children and adolescents with $\mathrm{CP}$. The CP-QoL-child form with primary caregiver proxy report was used in this trial. The domains included family and friends, participation in activities, communication, physical health, special equipment, pain and bother, access to services, and family health. Good internal consistency (Cronbach's alpha 0.61 to 0.87 ) and moderate to good test-retest reliability ( 0.47 to 0.84$)$ in all domains were reported in the Farsi version of questionnaire [37].

\section{Brain imaging}

MRI was performed on $1.5 \mathrm{~T}$ scanner (Philips Ingenia, Eindhoven, the Netherlands). All individuals had to be remained still and cover their ears with sponge earplugs for hearing protection. Intravenous propofol $(2 \mathrm{mg} / \mathrm{kg}$ dose) was used for sedation if participants did not cooperate and moved during imaging process. Intravenous thiopental ( $5 \mathrm{mg} / \mathrm{kg}$ dose) was used if there was sensitivity history to propofol. Possible side effects of propofol or thiopental were explained to the parents, and informed consent was obtained before using the medications. Heart and respiratory rates as well as oxygen saturation were monitored before and during the procedure. The protocol of MRI included 3D T1-weighted imaging (TR: $9.5 \mathrm{~ms}$, TE: $4.6 \mathrm{~ms}$, flip angle: $8^{\circ}$, FOV: $210 \times 210 \mathrm{~mm}^{2}$, voxel size: $1 \times 1 \times 1 \mathrm{~mm}^{3}$ ) and $2 \mathrm{D} \mathrm{T} 2$ weighted sequence (TR: $4000 \mathrm{~ms}$, TE: $110 \mathrm{~ms}$, flip angle: $90^{\circ}$, FOV: $230 \times 230 \mathrm{~mm}^{2}$, voxel size: $0.8 \times 0.8 \times 3.5$ $\mathrm{mm}^{3}$ ). The 2D T2-weighted sequence was used to acquire DTI data (TR: $4228 \mathrm{~ms}$, TE: $94 \mathrm{~ms}$, flip angle: $90^{\circ}$, FOV: $224 \times 224 \mathrm{~mm}^{2}$, voxel size: $2.5 \times 2.5 \times 2.5 \mathrm{~mm}^{3}$ ).

\section{Image post-processing}

DTI processing was performed using ExploreDTI software [38]. Post-processing included a cubic interpolation and robust estimation of tensors to correct for subject motion, eddy current, and EPI distortion. Non-rigid registration on the structural images was also performed. A whole-brain white matter tract construction was carried out for each participant using a linear interpolation. Seed point resolution was set at $1 \mathrm{~mm} \times 1 \mathrm{~mm} \times 1 \mathrm{~mm}$ with a seed fractional anisotropy threshold of 0.2 and an angle threshold of $50^{\circ}$.

Region of interest (ROI)-based tractography was performed. Predefined tracts such as corticospinal tract (CST) and posterior thalamic radiation (PTR) were isolated in both hemispheres. For segmentation of CST, first ROI "AND" was drawn at the pons level and the second ROI "AND" was drawn at the centrum semi oval level. To reject the fibers that project to the cerebellum via the middle cerebellar peduncle, ROI "NOT" was drawn. For illustration of PTR, first ROI was drawn at retro-lenticular part of the internal capsule and the second ROI was at the thalamus using "AND" operation. All other tracts that not related to the PTR and were outside to ROIs were eliminated by ROI "NOT" (Fig. 1). The mean value of fractional anisotropy (FA) and mean diffusivity (MD) were, then, estimated for each separated tract in both hemispheres. The two hemispheres of each participant were compared to each other, and data of the most affected tracts were used in the analysis.

\section{Cell preparation}

Allogenic UCT-MSCs were derived from umbilical cord tissues of unrelated donors. The ethics committee of Tehran University of Medical Sciences approved the methods (Number: IR.TUMS.VCRREC.1996.2506). The donors were selected from full-term healthy mothers who had normal vaginal delivery without complication. The written informed consents were provided to use the umbilical cords for medical research purposes. The blood samples of donors were collected and tested for reactive transmissible infectious agents including human immunodeficiency virus, hepatitis B virus, hepatitis C virus, and cytomegalovirus. After birth, the umbilical cords were detached from the placenta and put in the plates containing phosphate-buffered saline and streptomycin. They were transferred to the laboratories of Royan at $4^{\circ} \mathrm{C}$ within $24 \mathrm{~h}$. After removal of the umbilical arteries and vein, the umbilical cords were cut into 2 to $4 \mathrm{~cm}$ pieces to obtain Wharton's jelly. The Wharton's jelly was cut into $1 \mathrm{~mm}^{3}$ fragments. Collagenase and hyaluronidase were, then, added. The UCT-MSCs were isolated by centrifugation and cultivated in DMEM (Dulbecco's modified Eagle's medium) supplemented with $10 \%$ fetal bovine serum, $100 \mathrm{U} / \mathrm{mL}$ penicillin, $100 \mathrm{mg} /$ $\mathrm{mL}$ streptomycin, and $2 \mathrm{mmol} / \mathrm{L} \mathrm{L}$-glutamine and, then, incubated at $37^{\circ} \mathrm{C}$ in a humidified tissue culture incubator in $5 \% \mathrm{CO}_{2}$ and $95 \%$ air. The cells were passaged and 


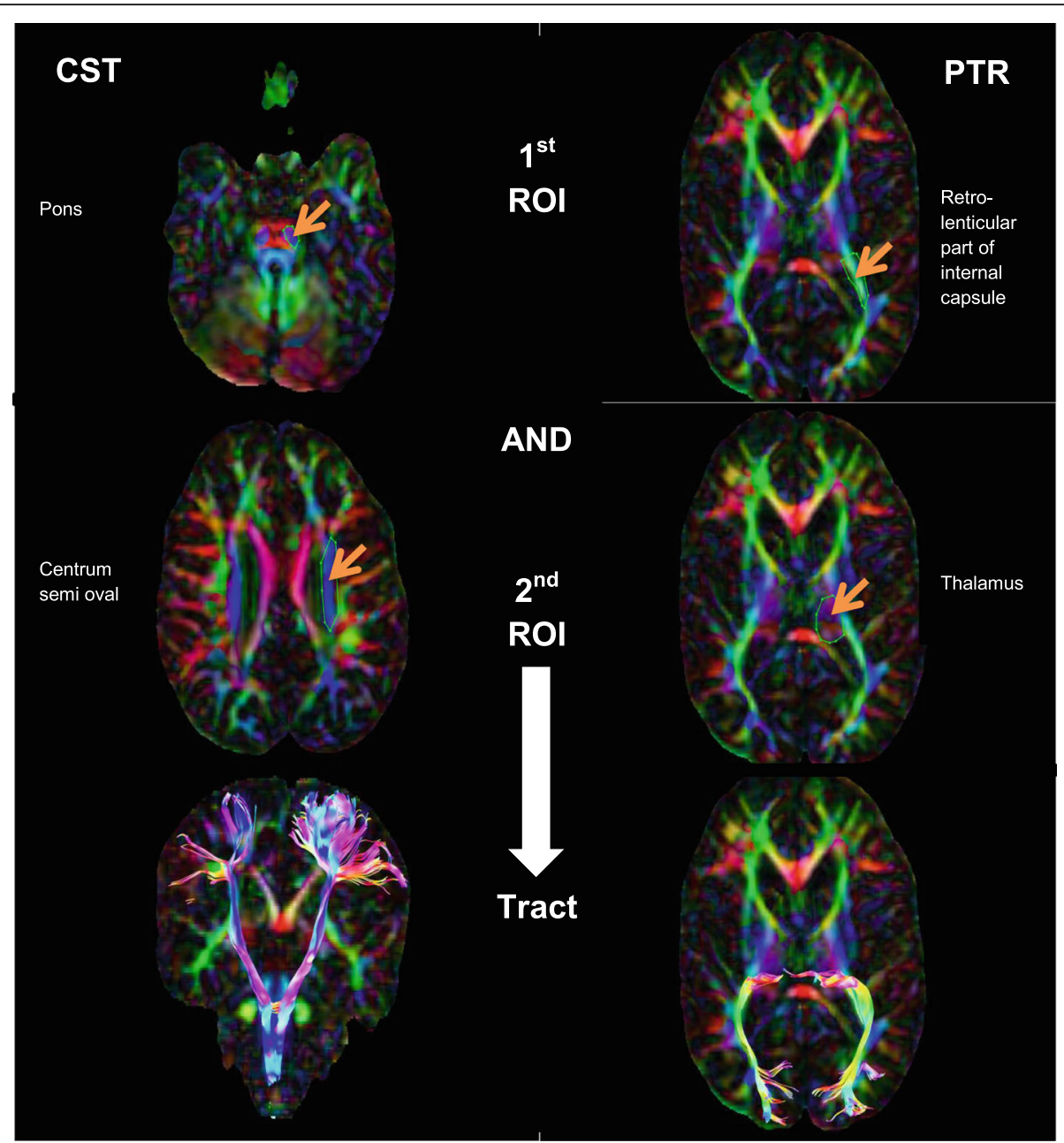

Fig. 1 The ROI-based tractography of the corticospinal tract and posterior thalamic radiation

collected at the fourth generation. Strict quality controls were performed before any clinical application. The products were analyzed for bacterial contamination using a BACTEC instrument (BD Bactec; BD Diagnostics, Franklin, NJ, http://www.bd.com). Furthermore, the amount of bacterial endotoxin was determined by limulus amebocyte lysate (LAL) kit (Lonza, Switzerland) and an ELISA reader (Amersham, USA). The cultivated cells were also tested to detect mycoplasma species by nested PCR, and karyotyping was performed to identify any chromosomal abnormalities. These procedures were conducted according to recommendations for cell and tissue therapy promotion and validation tests of the Iranian Health Ministry Pharmacopoeia Commission and the Department of Health and Human Services Food and Drug Administration.

The monoclonal antibodies against the cell surface markers CD11b, CD29, CD31, CD34, CD45, CD73, CD90, and CD105, as well as isotype control antibodies
(eBioscience) were used to stain the UCT-MSCs for $1 \mathrm{~h}$, and the analysis was performed using FACSCalibur (BD Biosciences). The flow cytometry analysis of UCT-MSCs was shown in Fig. 2.

\section{Double-blind treatment and follow-up phases}

Single dose of $2 \times 10^{7}$ cells were injected via intrathecal route in the experimental group. Cell suspensions were filtered through a cell strainer and transferred into storage vials. The cells were suspended in normal saline by unmasked personnel staff and then transferred for injection. Participants lied down on their sides (lateral decubitus position) with their knees drawn up to their chests. All participants were sedated and lumbar puncture was performed with 21 or 22 gauge spinal needles between lumbar level 2 and 5 intervertebral space after washing the back with iodine. The specific lumbar level was determined individually for each participant based on anatomical consideration. After assurance of placing 

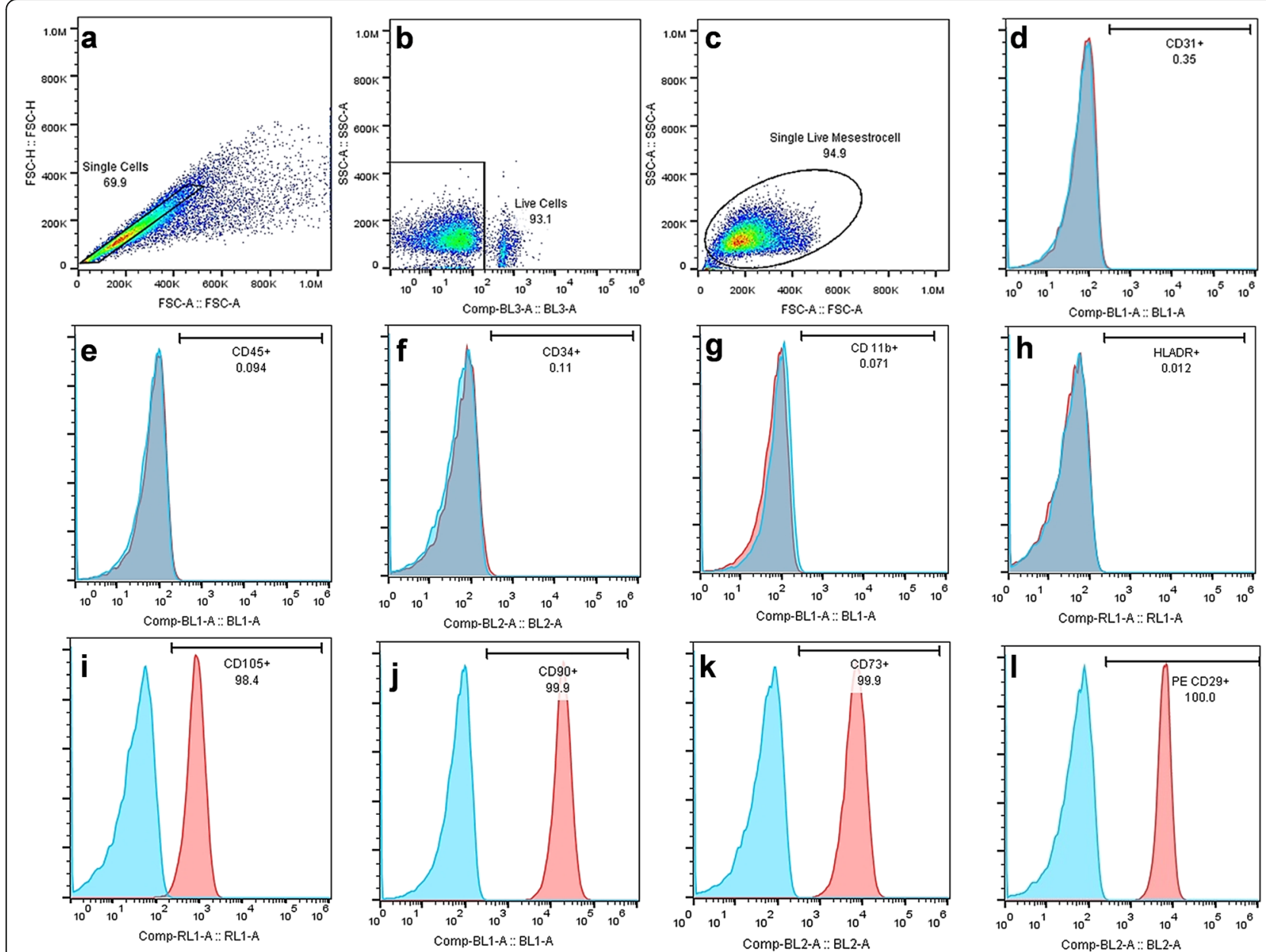

Fig. 2 The flow cytometry analysis of UCT-MSC-specific markers. The first three photos $(\mathbf{a}, \mathbf{b}, \mathbf{c})$ shows the cell gating to select single live UCTMSCs. Othe photos (d-l) shows that the cells were negative for CD11b, CD31, CD34, CD45, and HLA-DR and were positive for CD29, CD73, CD90, and CD105

the spinal needle in sub-arachnoid space, $2 \mathrm{~mL}$ of cerebrospinal fluid (CSF) was collected and $1 \mathrm{~mL}$ was sent to determine baseline CSF characteristics. The $2 \mathrm{~mL}$ of cells were, then, injected slowly within $2 \mathrm{~min}$. The $1 \mathrm{~mL}$ of remained CSF was infused in the last step and after cell injection. Sham procedure was performed in the control group. The puncture site was covered with a band-aid in all individuals (phase 3). All participants were hospitalized in child neurology departments. They were placed in $10^{\circ}$ trendelenburg position to maximize the distribution of cells in CSF. No immunosuppressive medications were used. Heart rates, temperature, blood pressure, and respiratory rates were monitored for $24 \mathrm{~h}$ after the intrathecal injection, and individuals were discharged if there were no side-effects. The GMFM-66 and MAS were assessed 1, 3, 6, and 12 months after the intervention. The PEDI and CP-QoL were evaluated 6 and 12 months after the procedure. MRI and DTI were also performed 12 months after treatment (phase 4).

\section{Outcomes}

Primary endpoints were the mean changes in GMFM-66 scores from baseline to 12 months after double-blind treatment phase. The mean changes in MAS, PEDI, and CP-QoL domains were also evaluated. The secondary endpoints were the mean changes in FA and MD of CST and PTR fibers from baseline to 12 months after the double-blind treatment phase. The differences between groups were also assessed.

Safety endpoints were the adverse events. All participants and their parents were asked to report any side effects during the follow-up visits. A phone number was given to the parents so adverse events could be reported as soon as possible. Parents were asked to bring their children to the emergency department if any serious complication occurred.

\section{Statistical analysis}

Sample size was estimated based on the mean changes in GMFM-66 scores. It was calculated using repeated 
measures analysis of variance (ANOVA) by G*Power 3.1 software (University of Kiel, Germany). Effect size of 0.25 , two-sided $\alpha$ (the probability of type I error) of 0.05 , and $\beta$ (the probability of type II error) of 0.20 were considered, and total sample size of 72 individuals was estimated after considering 10\% drop-out rate to provide at least $80 \%$ power (Supplement 3 ).

The statistician was blinded to study groups. Numeric variables were reported as means with standard deviation (SD) or standard error of the mean (SEM). Categorical variables were presented as percentages and were compared between groups using Pearson's chisquared test (gender, type of $\mathrm{CP}$, and GMFCS). Kolmogrov-Smirnov test was performed to report the distribution of variables. Two sided significance ( $P$ value) lower than 0.05 showed the non-normal distribution (GMFM-66, PEDI, and CP-QoL) and higher than 0.05 represented normal distribution of data (MAS and ROIbased data). Intention to treat approach was used and all participants who were randomized were included in the statistical analysis. Multiple imputation was conducted using Markov chain Monte Carlo to handle missing data. Generalized estimating equations (GEE) model was used to compare GMFM-66, PEDI, CP-QoL, and MAS mean scores between groups [39]. It was assumed that the interaction was between the intervention groups and time measurements. Exchangeable structure was considered for working correlation matrix and linear model was used. The model was adjusted to covariates including type of CP, GMFCS, gender, age, and weight of participants. Independent sample $t$ test was conducted to compare numeric variables in baseline and DTI data between groups. Statistical analyses were performed using the IBM SPSS Software, version 25.0 (SPSS Inc., Chicago, IL) and GraphPad Prism version 7.04. Twosided significance testing was conducted, and $P$ values< 0.05 were considered statistically significant. Cohen's $d$ test with $95 \%$ confidence interval $(\mathrm{CI})$ was used to measure the effect sizes that were classified as small $(d 0$ to $0.20)$, medium ( $d 0.20$ to 0.50$)$, and large $(d>0.50)$ using R statistical package (R Core Team, 2013).

\section{Results}

\section{Participants}

We used consolidated standards of reporting trials (CONSORT) to improve our study (Supplement 4). Initial screening started on July 23, 2017. The first participant was assigned to study group on August 19, 2017, and the double-blind treatment phase lasted until November 24, 2018. The follow-up phase lasted until December 2, 2019. Primary screening to identify eligible participants was performed on 321 individuals, and 72 cases were randomly assigned to study arms (36 cases in each group). There were 5 cases (6.9\%) who discontinued the study due to the lost to follow-up ( $n=3$ or $4.1 \%$ ) or withdrawal of consent ( $n=2$ or $2.8 \%$ ). Two participants (2.7\%) were examined during the follow-up periods, but the second imaging study was not conducted due to the parents' request (Fig. 3). Data showed that there were no differences between groups regarding the baseline demographic data (Table 1).

\section{Primary endpoint}

We included 72 participants in the analysis. The mean change in GMFM-66 scores from baseline to 12 months after intervention was statistically significant in the UCT-MSC group $(10.65,95 \%$ CI 5.39 to 15.91$)$ but not in control arm $(1.23,95 \% \mathrm{CI}-3.33$ to 5.80$)$ compared to baseline (Fig. 4A). The mean change was statistically higher in the experimental group compared to control arm with large effect size ( $\beta$ 8.07, 95\%CI 1.62 to 14.52 , Cohen's $d$ 0.92) (Table 2). The assessment of other scales showed that mean MAS scores from baseline to 12 months after cell injection decreased significantly (mean change $-1.0,95 \% \mathrm{CI}-1.31$ to -0.69 ) (Fig. 4B), and the mean change in the UCT-MSC group was statistically higher than control arm with large effect size $(\beta$ $-0.72,95 \%$ CI -1.18 to -0.26 , Cohen's $d 0.76$ ) (Table 2).

The analysis of PEDI data showed that self-care (mean change $3.43,95 \% \mathrm{CI} 1.79$ to 5.08 ) and mobility (mean change $3.88,95 \% \mathrm{CI} 1.48$ to 6.27 ) dimensions as well as total PEDI score (mean change $8.53,95 \% \mathrm{CI} 4.98$ to 12.08) increased significantly in the UCT-MSC group compared to baseline (Fig. 4C), and they were also significantly higher than the control group with large effect size (Cohen's $d>0.5$ ) (Table 3). Regarding CP-QoL, the mean changes in domains including friends and family, participation in activities, communication, and total scores were statistically higher than the control group with large effect size (Cohen's $d>0.5$ ) (Table 3), but there were no differences within groups that can show the changes were not clinically significant (Fig. 4D).

\section{Secondary endpoint}

The brain lesions in all participants were reported in Table 4. No significant improvements in the MRI of participants were observed compared to the baseline. The DTI analysis showed that mean FA increased significantly in the UCT-MSC group after 12 months of intervention (CST mean change: +0.032 , $95 \%$ CI 0.02 to 0.03 ; PTR mean change: $+0.024,95 \% \mathrm{CI} 0.020$ to 0.028 ) and was statistically higher than the control group with large effect size (CST Cohen's $d 0.81$ and PTR Cohen's $d$ 1.04) (Table 5). The mean MD decreased significantly in the experimental group after 12 months of intrathecal cell injections (CST mean change $-0.035 \times 10^{-3}, 95 \% \mathrm{CI}-0.04 \times 10^{-3}$ to $-0.02 \times 10^{-3}$; PTR mean change $-0.045 \times 10^{-3}, 95 \% \mathrm{CI}-0.05 \times 10^{-3}$ to $-0.03 \times 10^{-3}$ ) and was statistically lower than the control 


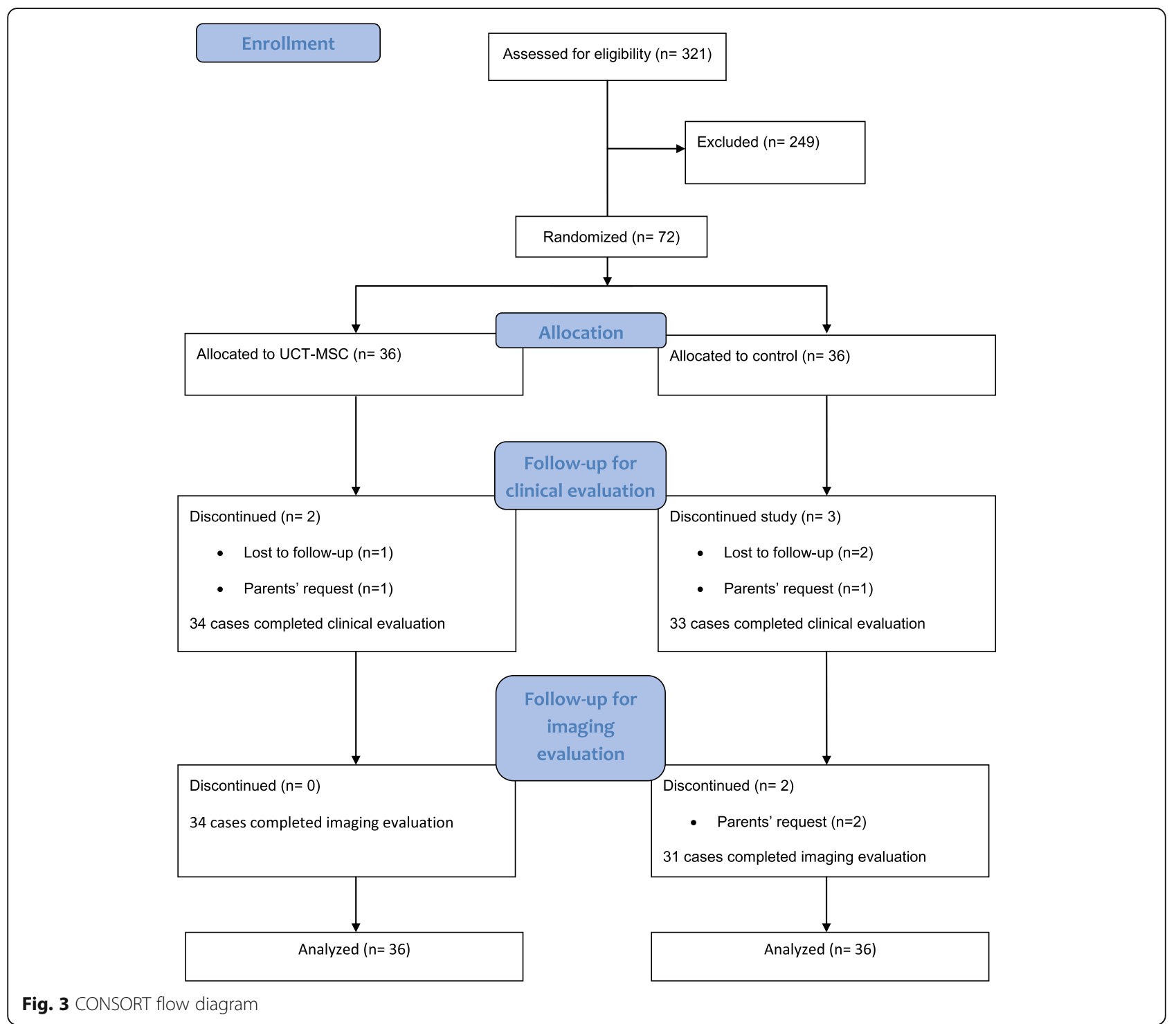

group with large effect size (CST Cohen's $d 0.77$ and PTR Cohen's $d$ 0.55) (Table 5).

\section{Safety endpoint}

There were 5 adverse events that were identified in participants. Two cases in the UCT-MSC group (2/36 or $5.5 \%$ ) experienced fever ( 38 to $38.7^{\circ} \mathrm{C}$ ) within $24 \mathrm{~h}$ of intrathecal cell injections but resolved spontaneously and with no diagnosis of infection (e.g., meningitis). Mild to moderate irritability ( $n=3$ control group and $n=6$ UCT-MSC group), headache ( $n=1$ control group and $n=5$ UCT-MSC group); low back pain ( $n=8$ UCT-MSC group); and vomiting ( $n=1$ UCT-MSC group) were other reported adverse events within $24 \mathrm{~h}$ after procedures. These primary events were recorded by nurses and medical doctors who were not informed about the study. These data were not shared with the investigators until the end of the study. All symptoms were resolved, and no serious adverse events were reported during the follow-up periods.

\section{Discussion}

This study assessed the safety and efficacy of intrathecal administration of a single dose of the UCT-MSC in children with $\mathrm{CP}$ in referral hospitals. The data of GMFM66, PEDI, CP-QoL, and MAS scores showed that cell therapy was clinically effective. The data of DTI also showed significant improvements in white matter structural integrity of cases treated with stem cells. The intrathecal injection of the cells was safe in participants, and there was no difference in serious adverse events compared to the control group. 
Table 1 Baseline demographic characteristics

\begin{tabular}{|c|c|c|c|}
\hline Demographics & $\begin{array}{l}\text { Control } \\
n=36\end{array}$ & $\begin{array}{l}\text { UCT-MSC } \\
n=36\end{array}$ & $P$ value \\
\hline \multicolumn{4}{|l|}{ Gender N (\%) } \\
\hline Female & $17(47.2)$ & $15(41.7)$ & 0.339 \\
\hline Male & $19(52.8)$ & $21(58.3)$ & \\
\hline \multicolumn{4}{|l|}{ Age (months) } \\
\hline Mean (SD) & $102.5(29.9)$ & $101.7(32.1)$ & 0.186 \\
\hline \multicolumn{4}{|l|}{ Weight (kg) } \\
\hline Mean (SD) & $17.3(7.2)$ & $17.5(8.5)$ & 0.30 \\
\hline \multicolumn{4}{|l|}{ Type of cerebral palsy } \\
\hline Spastic quadriplegia & $32(88.9)$ & $30(83.3)$ & 0.491 \\
\hline Spastic diplegia & $4(11.1)$ & $6(16.7)$ & \\
\hline \multicolumn{4}{|l|}{ GMFCS, N } \\
\hline$\|/\| / I V N$ & $4 / 4 / 11 / 17$ & $5 / 7 / 10 / 14$ & 0.876 \\
\hline \multicolumn{4}{|l|}{ GMFM-66 score } \\
\hline Mean (SD) & $66.3(50.7)$ & $70.2(45.0)$ & 0.769 \\
\hline \multicolumn{4}{|l|}{ Modified Ashworth scale } \\
\hline Mean (SD) & $3.16(0.97)$ & $2.91(1.12)$ & 0.215 \\
\hline \multicolumn{4}{|l|}{ PEDI-Self-care } \\
\hline Mean (SD) & $21.77(16.15)$ & $24.37(17.09)$ & 0.518 \\
\hline \multicolumn{4}{|l|}{ PEDI-Mobility } \\
\hline Mean (SD) & $16.07(14.01)$ & $17.53(11.98)$ & 0.682 \\
\hline \multicolumn{4}{|l|}{ PEDI-Social function } \\
\hline Mean (SD) & $26.63(18.76)$ & $32.08(20.33)$ & 0.243 \\
\hline \multicolumn{4}{|l|}{ CP-QOL } \\
\hline Mean (SD) & $369.8(56.2)$ & $364.4(46.1)$ & 0.644 \\
\hline \multicolumn{4}{|l|}{ FA corticospinal tract } \\
\hline Mean (SD) & $0.433(0.63)$ & $0.448(0.40)$ & 0.371 \\
\hline \multicolumn{4}{|c|}{ FA posterior thalamic radiate } \\
\hline Mean (SD) & $0.341(0.40)$ & $0.354(0.32)$ & 0.364 \\
\hline \multicolumn{4}{|l|}{ MD corticospinal tract ${ }^{*}$} \\
\hline Mean (SD) $\times 10^{3}$ & $0.967(0.07)$ & $0.972(0.06)$ & 0.271 \\
\hline \multicolumn{4}{|c|}{ MD posterior thalamic ${ }^{*}$ radiate } \\
\hline Mean $(\mathrm{SD}) \times 10^{3}$ & $1.060(0.12)$ & $1.067(0.07)$ & 0.943 \\
\hline
\end{tabular}

SD standard deviation, GMFCS growth motor classification system, GMFM growth motor function measurement, $P E D I$ pediatric evaluation of disability inventory, $C P-Q O L$ cerebral palsy quality of life child, FA fractional anisotropy, $M D$ mean diffusivity

*The means (SD) should be divided by 1000

Motor impairments are the most common disability symptoms in CP. Our study showed that intrathecal injection of the UCT-MSC improved motor function significantly after 6 months of cell injection compared to the control group. The improvements remained until the end of follow-up visits. One non-randomized trial on 8 pairs (16 individuals) of identical twins reported that gross motor function had no significant improvements after 1 month of 4-6 × 10 7 allogenic UCT-MSC intrathecal injection but significant improvements were observed after 6 months. Hereditary factor was reported to be a predictor of efficacy [40]. Our study showed that the mean GMFM66 scores decreased and MAS increased in the experimental group at the last follow-up visit (1 year) compared to the previous one (6 months). This may show the temporary effects of cell transplantations in CP. Increasing injection frequency may improve the efficacy in longer periods. The overall changes in the mean GMFM-66 scores in both groups of our trial were lower compared to the literature [41-43]. This can be due to the baseline characteristics including the age of participants. The mean age of our included cases was higher than prior studies [41-43]. It has been shown that the potential of growth motor in children with CP plateaus after 5 to 7 years of age [44], and we could expect better treatment responses in individuals with ages closer to the timing of the injury [21]. Furthermore, the lower mean change in the treatment group could also be due to the single-dose injection of UCT-MSCs.

Emerging evidence showed that stem cells derived from different sources could be plausible treatments to improve motor function in people with $\mathrm{CP}$. A recent randomized clinical trial reported that four intrathecal injections of autologous bone marrow MSC improved gross and fine motor functions compared to the placebo [41]. It should be noted that cord cell transplant is generally better-suited in children and adolescents as cells can be collected safely and without invasive and painful procedures. The use of allogenic umbilical cord cells is also cheaper and less time-consuming than the use of autologous bone marrow cells. The separation, purification, expansion, characterization, and harvest of MSCs from the bone marrow could take much longer time (about 1 month) than UCT-MSCs [40]. Other clinical studies used bone marrow mononuclear cells $[45,46]$ or MSC [47] reported significant functional improvements. The human embryonic tissue is another source of stem cells that was shown to be safe and effective in individuals with CP [48]. This source, however, cannot be used in many clinical conditions due to difficulties in isolation methods and requirement for a complex culture system [49]. Furthermore, harvesting of cells can lead to death of embryo that raises major ethical concerns. Neural progenitor cells and olfactory ensheathing cells were other effective cell types used in children with $\mathrm{CP}$ and isolated from aborted human fetuses [50, 51].

Stem cells can be administered by different routes. The most appropriate route was, however, unknown. Several studies reported that intravenous or intraarterial infusions of stem cells can accelerate the functional development of people with CP [52-54]. Although cell transplant by these routes is less invasive than intrathecal cell injection; studies showed that fewer cells than expected could reach to the lesion areas using intra- 


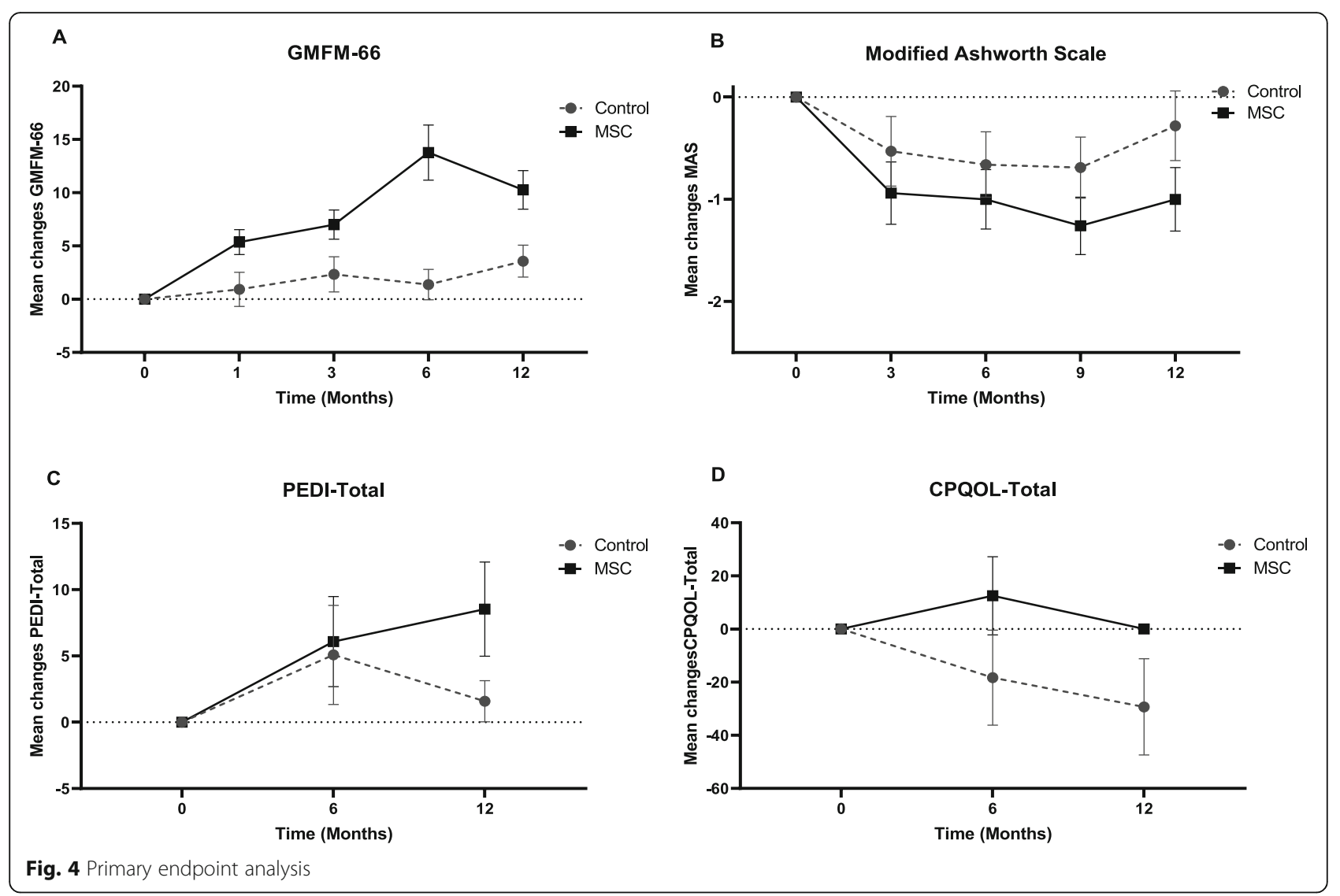

arterial/intravenous deliveries due to the possible retaining by other organs or inability of cells to cross the blood brain barrier $[55,56]$. Intra-arterial cell infusions were also showed to be associated with increased risk of micro-embolic events [57]. One case-report used the combination of intravenous and intrathecal deliveries of UCT-MSC and reported obvious improvements in EEG, motor function, and language expression [58]. Intraventricular route of cell administration was also suggested but is more invasive and cannot be used generally in all patients [50].

The data of quantitative DTI can be so helpful to measure the alterations of white matter integrity after cell transplant. To date, few studies assessed the changes

Table 2 The GMFM-66 and MAS mean difference within-groups (from baseline) and the difference between groups

\begin{tabular}{|c|c|c|c|c|c|c|}
\hline \multirow[t]{3}{*}{ Outcomes } & \multicolumn{2}{|c|}{$\begin{array}{l}\text { Test of within-group (mean change } \\
\text { from effects of baseline) }\end{array}$} & \multirow{2}{*}{\multicolumn{4}{|c|}{$\begin{array}{l}\text { Test of between-groups effects } \\
\text { (mean change from the control group) } \\
\text { MSC vs control }\end{array}$}} \\
\hline & \multirow{2}{*}{$\begin{array}{l}\text { Control } \\
\text { Mean }[95 \% \mathrm{Cl}]\end{array}$} & \multirow{2}{*}{$\begin{array}{l}\text { MSC } \\
\text { Mean }[95 \% \mathrm{Cl}]\end{array}$} & & & & \\
\hline & & & $\beta$ & $95 \% \mathrm{Cl}$ & P.v & Cohen's $d[95 \% \mathrm{Cl}]$ \\
\hline \multicolumn{7}{|l|}{ GMFM-66 } \\
\hline $\mathrm{T} 1$ & $-0.02[-4.79,4.75]$ & $4.47[-0.73,9.68]$ & 4.59 & {$[-1.16,10.35]$} & 0.11 & $0.45[-0.01,0.92]$ \\
\hline $\mathrm{T} 2$ & $2.03[-2.97,7.04]$ & $6.85[1.49,12.20]$ & 4.81 & {$[-0.23,9.86]$} & 0.062 & $0.48[-0.01,0.93]$ \\
\hline T3 & $-0.58[-5.32,4.15]$ & $11.27[6.01,16.53]$ & 11.90 & {$[5.42,18.37]$} & $<0.001$ & $1.11[0.54,1.67]$ \\
\hline T4 & $1.23[-3.33,5.80]$ & $10.65[5.39,15.91]$ & 8.07 & {$[1.62,14.52]$} & 0.002 & $0.92[0.34,1.48]$ \\
\hline \multicolumn{7}{|l|}{ MAS } \\
\hline $\mathrm{T} 1$ & $-0.53[-0.87,-0.18]$ & $-0.94[-1.24,-0.63]$ & -0.41 & {$[-0.87,0.04]$} & 0.074 & $0.22[-0.31,0.75]$ \\
\hline $\mathrm{T} 2$ & $-0.66[-0.99,-0.34]$ & $-1.0[-1.29,-0.70]$ & -0.33 & {$[-0.77,0.10]$} & 0.132 & $0.11[-0.37,0.60]$ \\
\hline T3 & $-0.69[-1.03,-0.35]$ & $-1.26[-1.56,-0.95]$ & -0.56 & {$[-1.01,-0.11]$} & 0.014 & $0.37[0.14,0.89]$ \\
\hline T4 & $-0.28[-0.62,0.05]$ & $-1.0[-1.31,-0.69]$ & -0.72 & {$[-1.18,-0.26]$} & 0.002 & $0.76[0.20,1.31]$ \\
\hline
\end{tabular}


Table 3 The PEDI and CP-QoL mean difference within-groups (from baseline) and the difference between groups

\begin{tabular}{|c|c|c|c|c|c|c|}
\hline \multirow[t]{3}{*}{ Outcomes } & \multicolumn{2}{|c|}{$\begin{array}{l}\text { Test of within-group mean change } \\
\text { from effects of baseline }\end{array}$} & \multirow{2}{*}{\multicolumn{4}{|c|}{$\begin{array}{l}\text { Test of between-groups effects } \\
\text { mean change control group } \\
\text { MSC vs control }\end{array}$}} \\
\hline & \multirow{2}{*}{$\begin{array}{l}\text { Control } \\
\text { Mean }[95 \% \mathrm{Cl}]\end{array}$} & \multirow{2}{*}{$\begin{array}{l}\text { MSC } \\
\text { Mean }[95 \% \mathrm{Cl}]\end{array}$} & & & & \\
\hline & & & $\beta$ & {$[95 \% \mathrm{Cl}]$} & P.v & Cohen's $d[95 \% \mathrm{Cl}]$ \\
\hline \multicolumn{7}{|c|}{ PEDI self-care } \\
\hline T3 & $1.89[0.16,3.62]$ & $1.94[0.39,3.50]$ & -0.01 & {$[-2.36,2.35]$} & 0.99 & $0.01[-0.5,0.56]$ \\
\hline T4 & $0.15[-1.63,1.95]$ & $3.43[1.79,5.08]$ & 3.22 & {$[0.75,5.69]$} & 0.011 & $0.79[0.22,1.32]$ \\
\hline \multicolumn{7}{|c|}{ PEDI mobility } \\
\hline $\mathrm{T} 3$ & $0.13[-1.69,1.91]$ & $1.63[-0.62,3.90]$ & 1.53 & {$[-1.38,4.38]$} & 0.29 & $0.33[-017,0.84]$ \\
\hline $\mathrm{T} 4$ & $0.81[-1.09,2.72]$ & $3.88[1.48,6.27]$ & 3.19 & {$[0.16,6.22]$} & 0.039 & $0.62[0.07,1.17]$ \\
\hline \multicolumn{7}{|c|}{ PEDI social function } \\
\hline T3 & $3.04[0.86,5.23]$ & $2.56[1.01,4.12]$ & -0.52 & {$[-3.30,2.25]$} & 0.71 & $0.09[-0.60,0.42]$ \\
\hline T4 & $1.35[-0.93,3.60]$ & $1.60[-0.02,3.23]$ & 0.20 & {$[-2.69,3.09]$} & 0.89 & $0.08[-0.45,0.62]$ \\
\hline \multicolumn{7}{|l|}{ PEDI total } \\
\hline T3 & $5.09[1.35,8.83]$ & $6.08[2.68,9.47]$ & 0.89 & {$[-4.23,6.02]$} & 0.73 & $0.11[-0.40,0.62]$ \\
\hline $\mathrm{T} 4$ & $1.58[-2.30,5.46]$ & $8.53[4.98,12.08]$ & 6.87 & {$[1.52,12.21]$} & 0.012 & $0.70[0.14,1.23]$ \\
\hline \multicolumn{7}{|l|}{ CPQOL } \\
\hline \multicolumn{7}{|c|}{ Friends and family } \\
\hline $\mathrm{T} 3$ & $-1.78[-8.78,5.20]$ & $5.0[-1.08,11.09]$ & 6.92 & {$[-2.36,16.22]$} & 0.14 & $0.42[-0.09,0.93]$ \\
\hline T4 & $-10.36[-17.45,-3.28]$ & $0.92[-5.33,7.18]$ & 11.23 & {$[1.74,20.71]$} & 0.020 & $0.63[0.1,1.16]$ \\
\hline \multicolumn{7}{|c|}{ Participate in activities } \\
\hline T3 & $-2.20[-4.84,0.43]$ & $1.02[-1.28,3.33]$ & 3.21 & {$[-0.30,6.73]$} & 0.074 & $0.45[-0.06,0.97]$ \\
\hline $\mathrm{T} 4$ & $-4.20[-6.88,-1.53]$ & $0.49[-1.84,2.87]$ & 4.61 & {$[1.01,8.20]$} & 0.012 & $0.65[0.11,1.19]$ \\
\hline \multicolumn{7}{|c|}{ Communication } \\
\hline T3 & $-2.65[-4.42,-0.88]$ & $-1.18[-2.95,0.59]$ & 1.50 & {$[-1.00,4.00]$} & 0.241 & $0.29[-0.20,0.78]$ \\
\hline $\mathrm{T} 4$ & $-1.99[-3.83,-0.15]$ & $0.56[-1.29,2.43]$ & 2.54 & {$[0-0.06,5.16]$} & 0.05 & $0.63[0.1,1.16]$ \\
\hline \multicolumn{7}{|c|}{ Physical health } \\
\hline T3 & $-1.27[-6.78,4.29]$ & $6.85[1.17,12.52]$ & 8.15 & {$[0.25,16.06]$} & 0.043 & $0.58[0.06,1.10]$ \\
\hline T4 & $-3.54[-9.12,2.02]$ & $2.0[-3.82,7.84]$ & 5.34 & {$[-2.71,13.41]$} & 0.19 & $0.40[-0.12,0.93]$ \\
\hline \multicolumn{7}{|c|}{ Special equipment } \\
\hline T3 & $-0.74[-2.95,1.42]$ & $0.35[-1.89,2.59]$ & 1.08 & {$[-2.0,4.21]$} & 0.49 & $0.13[-0.37,0.64]$ \\
\hline T4 & $0.45[-1.76,2.67]$ & $-1.32[-3.63,0.97]$ & -1.71 & {$[-4.91,1.48]$} & 0.29 & $0.31[-0.84,0.21]$ \\
\hline \multicolumn{7}{|c|}{ Pain and impact of disability } \\
\hline T3 & $-0.86[-6.33,4.59]$ & $3.41[-0.76,7.59]$ & 4.42 & {$[-2.11,11.36]$} & 0.21 & $0.25[-0.26,0.76]$ \\
\hline T4 & $1.31[-4.22,6.58]$ & $3.52[-0.77,7.82]$ & 0.70 & {$[-4.55,9.59]$} & 0.48 & $0.16[-0.36,0.68]$ \\
\hline \multicolumn{7}{|c|}{ Access to services } \\
\hline T3 & $-6.09[-11.43,-0.74]$ & $-4.31[-9.52,0.89]$ & 1.64 & {$[-5.82,9.11]$} & 0.66 & $0.14[-0.37,0.65]$ \\
\hline T4 & $-8.66[-14.08,-3.24]$ & $-4.93[-10.28,0.42]$ & 4.0 & {$[-03.61,11.62]$} & 0.30 & $0.24[-0.28,0.77]$ \\
\hline \multicolumn{7}{|c|}{ Family health } \\
\hline $\mathrm{T} 3$ & $-3.28[-6.21,-0.35]$ & $0.39[-1.86,2.64]$ & 3.66 & {$[-0.5,7.38]$} & 0.054 & $0.49[-0.02,1.01]$ \\
\hline $\mathrm{T} 4$ & $-2.52[-5.49,0.44]$ & $-1.09[-3.40,1.22]$ & 1.29 & {$[-2.49,5.09]$} & 0.503 & $0.21[-0.31,0.73]$ \\
\hline \multicolumn{7}{|l|}{ CPQOL-total } \\
\hline $\mathrm{T} 3$ & $-18.3[-36.19,-0.37]$ & $12.5[-2.27,27.23]$ & 30.74 & {$[-0.24,0.57]$} & 0.010 & $0.65[0.13,1.17]$ \\
\hline $\mathrm{T} 4$ & $-29.3[-47.5,-11.2]$ & $0.05[-15.11,15.22]$ & 29.27 & {$[5.50,53.04]$} & 0.016 & $0.68[0.14,1.22]$ \\
\hline
\end{tabular}


Table 4 The brain lesions of participants using magnetic resonance imaging

\begin{tabular}{lll}
\hline Findings & UCT-MSC group & Control group \\
\hline Periventricular leukomalacia & $32(88.9 \%)$ & $30(83.3 \%)$ \\
Ventriculomegaly & $17(42.2 \%)$ & $15(41.7 \%)$ \\
Corpus callosum agenesis & $6(16.7 \%)$ & $8(22.2 \%)$ \\
Cerebral atrophy & $2(5.5 \%)$ & $9(25.0 \%)$ \\
Basal ganglia involvement & $2(5.5 \%)$ & $4(11.1 \%)$ \\
Focal ischemia & $0(0.0 \%)$ & $2(5.5 \%)$ \\
Cystic encephalomalacia & $1(2.8 \%)$ & $2(5.5 \%)$ \\
Porencephalic cyst & $1(2.8 \%)$ & $1(2.8 \%)$ \\
\hline
\end{tabular}

in DTI parameters after cell therapy in different disorders [59-61]. The ROI-based analysis of CST in individuals with CP reported significant reductions in FA [62-66] and increased MD [67] compared to the healthy individuals. It was shown that GMFCS was associated with the FA of CST when assessing ROI-based fractional anisotropy $[62,64,65,68]$. Some studies reported significant FA reductions in PTR of cases with CP [62, 69]. The ROIbased fractional anisotropy of PTR was also shown to be correlated with the GMFCS levels [62, 68, 69]. Our results showed that cell transplant increased FA and decreased MD of both CST and PTR significantly. These changes can show that the diffusion of water molecules is constrained in the CST and PTR after cell therapy that could be associated with increased rate of myelination and improvements in white-matter structural integrity.

This trial had different strengths. To our knowledge, this is the first clinical trial used quantitative DTI after intrathecal cell injection in individuals with CP. Randomization and blinding were other main strengths of this study. The multi-center prospective populationbased approach of this trial enhanced the external validity of the results. There were also some limitations to our study. Single and fixed dose of UCT-MSC was administered in our participants. Repeated injections based on weights of individuals might increase the efficacy of the cells. Further studies should compare different routes and sources of stem cells to find the most appropriate protocol of cell transplant. The optimal dose of cells can be identified by conducting cross-over studies. Longer follow-up periods are suggested to realize the long-term efficacy of cell transplant. Using other imaging data including magnetic resonance spectroscopy

Table 5 Secondary endpoint analysis

\begin{tabular}{|c|c|c|}
\hline Outcome & UCT-MSC $(n=36)$ & control $(n=36)$ \\
\hline \multicolumn{3}{|l|}{ Fractional anisotropy } \\
\hline \multicolumn{3}{|l|}{ Corticospinal tract } \\
\hline 12 months mean (SD) & $0.48(0.04)$ & $0.42(0.06)$ \\
\hline Mean changes from baseline $(95 \% \mathrm{Cl})$ & 0.032 (0.02 to 0.03$)$ & $-0.007(-0.010$ to -0.002$)$ \\
\hline Difference vs control (95\% Cl) & 0.055 (0.02 to 0.08 ) & - \\
\hline Cohen's d (95\%Cl) & $0.81(0.36$ to 1.26$)$ & - \\
\hline \multicolumn{3}{|l|}{ Posterior thalamic radiate } \\
\hline 12 months mean (SD) & $0.37(0.03)$ & $0.32(0.04)$ \\
\hline Mean changes from baseline $(95 \% \mathrm{Cl})$ & 0.024 (0.020 to 0.028$)$ & $-0.020(-0.02$ to -0.01$)$ \\
\hline Difference vs control $(95 \% \mathrm{Cl})$ & 0.059 (0.3 to 0.8 ) & - \\
\hline Cohen's d $(95 \% \mathrm{Cl})$ & 1.04 (0.68 to 1.41$)$ & - \\
\hline \multicolumn{3}{|l|}{ Mean diffusivity $\left(\times 10^{3}\right)^{*}$} \\
\hline \multicolumn{3}{|l|}{ Corticospinal tract } \\
\hline 12 months mean (SD) & $0.93(0.05)$ & $1.00(0.12)$ \\
\hline Mean changes from baseline $(95 \% \mathrm{Cl})$ & $-0.035(-0.04$ to -0.02$)$ & 0.040 (0.02 to 0.05$)$ \\
\hline Difference vs control (95\% Cl) & $-0.07(-0.11$ to -0.02$)$ & - \\
\hline Cohen's $d(95 \% \mathrm{Cl})$ & 0.77 (0.26 to 1.28$)$ & - \\
\hline \multicolumn{3}{|l|}{ Posterior thalamic radiate } \\
\hline 12 months mean (SD) & $1.02(0.07)$ & $1.09(0.19)$ \\
\hline Mean changes from baseline (95\% Cl) & $-0.045(-0.05$ to -0.03$)$ & 0.033 (0.01 to 0.05$)$ \\
\hline Difference vs control (95\% Cl) & $-0.07(-0.15$ to -0.003$)$ & - \\
\hline Cohen's d (95\%Cl) & $0.55(0.01$ to 1.11$)$ & - \\
\hline
\end{tabular}

*The mean (SD) should be divided by 1000 
can also be useful to better understand the underlying mechanisms of stem cells in neuronal repair.

\section{Conclusions}

The intrathecal injection of the UCT-MSC may be safe in children diagnosed with $\mathrm{CP}$ and improve the clinical and imaging outcomes.

\section{Abbreviations \\ ANOVA: Analysis of variance; Cl: Confidence interval; CNS: Central nervous system; CP: Cerebral palsy; CP-QoL: Cerebral palsy quality of life; CST: Corticospinal tract; DMEM: Dulbecco's modified Eagle's medium; DTI: Diffusion tensor imaging; EEG: Electro-encephalography; FA: Fractional anisotropy; GEE: Generalized estimating equations; GMFCS: Gross motor function classification system; GMFM: Gross motor function measure; LAL: Limulus amebocyte lysate; MD: Mean diffusivity; MAS: Modified Ashworth scale; MRI: Magnetic resonance imaging; PEDI: Pediatric evaluation of disability inventory; PTR: Posterior thalamic radiation; ROI: Region of interest; SD: Standard deviation; SEM: Standard error of the mean; UCT- MSC: Umbilical cord tissue mesenchymal stem cell}

\section{Supplementary information}

The online version contains supplementary material available at https:/doi. org/10.1186/s13287-021-02513-4

Additional file 1: Supplement 1. Levels of gross motor function

classification system (GMFCS).

Additional file 2: Supplement 2. Modified Ashworth scale

Additional file 3: Supplement 3. Sample size calculation

Additional file 4: Supplement 4. CONSORT 2010 checklist of

information to include when reporting a randomised trial*

\section{Acknowledgements}

The authors are grateful to all parents and patients for their participation in this study. Our special thanks to Mr. Abolfazl Abdi, Mrs. Asa Fazilat, Dr. Samira Raminfard, Dr. Houman Alizadeh, and Dr. Neda Pak for analyses of DTI data.

\section{Authors' contributions}

MA, ARM, and MRA conducted the study design. SN and MGA performed the rehabilitation therapy. $\mathrm{HoM}, \mathrm{HaM}, \mathrm{AM}, \mathrm{MZ}, \mathrm{MN}, \mathrm{RSB}, \mathrm{AAH}$, and MV performed data acquisition. $\mathrm{OG}, \mathrm{FZ}$, and $\mathrm{MH}$ conducted the brain imaging of participants. MA and ART performed the interpretation of data and statistical analysis. MA and MS prepared the draft of the manuscript. AF and AG revised the paper before submission. The author(s) read and approved the final manuscript.

\section{Funding}

The Research Deputy of Tehran University of Medical Sciences provided financial and logistic support for this trial but had no role in study design, the collection, analysis, and interpretation of data, in the writing of the report, or in the decision to submit the article for publication.

\section{Availability of data and materials}

The datasets generated and/or analyzed during the current study are not publicly available but are available from the corresponding author on reasonable request.

\section{Declarations}

\section{Ethics approval and consent to participate}

The procedures were fully explained to the participants and their parents. Ethics committee of Tehran University of Medical Sciences approved the final methods (Number: IR.TUMS.VCRREC.1996.2506). Parents of participants had access to all information. They were informed that participation was optional and withdrawal was possible whenever they asked for.
Consent for publication

Not applicable.

\section{Competing interests}

The authors declare that they have no competing interests.

\section{Author details}

'Department of Science and Research Branch, AJA University of Medical Sciences, Tehran, Iran. ${ }^{2}$ Pediatrics Center of Excellence, Department of Pediatric Neurology, Children's Medical Center, Growth and Development Research Center, Tehran University of Medical Sciences, Tehran, Iran. ${ }^{3}$ Department of Regenerative Medicine, Cell Science Research Center, Royan Institute for Stem Cell Biology and Technology, ACECR, Tehran, Iran. ${ }^{4}$ Department of Pediatric Neurology, Clinical Research Development Center of Children Hospital, Hormozgan University of Medical Sciences, Bandar Abass, Iran. ${ }^{5}$ Pediatrics Center of Excellence, Department of Radiology, Children's Medical Center, Tehran University of Medical Sciences, Tehran, Iran. ${ }^{6}$ Clinical Biomechanics and Ergonomics Research Center, Department of Physical Medicine and Rehabilitation, Faculty of Medicine, AJA University of Medical Sciences, Tehran, Iran. ${ }^{7}$ Pediatrics Center of Excellence Pediatric Hematology, Oncology and Stem Cell Transplantation Department, Children's Medical Center, Tehran University of Medical Sciences, Tehran, Iran. ${ }^{8}$ Psychiatry and Psychology Research Center, Tehran University of Medical Sciences, Tehran, Iran. ${ }^{9}$ Department of Pediatrics, Faculty of Medicine, Tehran Medical Sciences, Islamic Azad University, Tehran, Iran. ${ }^{10}$ Department of Pediatric Neurology, AJA University of Medical Sciences, Tehran, Iran. ${ }^{11}$ Moser Center for Leukodystrophies, Kennedy Krieger Institute, Baltimore, MD 21205, USA. ${ }^{12}$ Department of Neurology and Pediatrics, Johns Hopkins University School of Medicine, Baltimore, MD 21287, USA. ${ }^{13}$ Department of Psychiatry, Yale School of Medicine, New Haven, CT, USA. ${ }^{14}$ Department of Psychiatry, Icahn School of Medicine at Mount Sinai, New York, NY, USA.

Received: 15 December 2020 Accepted: 8 June 2021

Published online: 06 August 2021

\section{References}

1. Lindvall O, Kokaia Z. Stem cells for the treatment of neurological disorders. Nature. 2006;441(7097):1094-6. https://doi.org/10.1038/nature04960.

2. Prasad K, Sharma A, Garg A, Mohanty S, Bhatnagar S, Johri S, et al. Intravenous autologous bone marrow mononuclear stem cell therapy for ischemic stroke: a multicentric, randomized trial. Stroke. 2014;45(12):361824. https://doi.org/10.1161/STROKEAHA.114.007028.

3. Mancardi GL, Sormani MP, Gualandi F, Saiz A, Carreras E, Merelli E, et al. Autologous hematopoietic stem cell transplantation in multiple sclerosis: a phase II trial. Neurology. 2015;84(10):981-8. https://doi.org/10.1212/WNL. 0000000000001329

4. Venkataramana NK, Kumar SK, Balaraju S, Radhakrishnan RC, Bansal A, Dixit A, et al. Open-labeled study of unilateral autologous bone-marrow-derived mesenchymal stem cell transplantation in Parkinson's disease. Transl Res. 2010;155(2):62-70. https://doi.org/10.1016/j.trsl.2009.07.006.

5. Bachoud-Lévi AC. Multicentric Intracerebral Grafting in Huntington's, Schramm C, Remy P, Aubin G, Blond S, Bocket L, Brugières P, Calvas F, Calvier E, Cassim F. Human Fetal cell therapy in Huntington's disease: a randomized, multicenter, phase ii trial. Mov Disord. 2020;35(8):1323-35. https://doi.org/10.1002/mds.28201.

6. Zhu H, Poon W, Liu Y, Leung GK, Wong Y, Feng Y, et al. Phase I-II clinical trial assessing safety and efficacy of umbilical cord blood mononuclear cell transplant therapy of chronic complete spinal cord injury. Cell Transplant. 2016;25(11):1925-43. https://doi.org/10.3727/096368916X691411.

7. Baraniak PR, McDevitt TC. Stem cell paracrine actions and tissue regeneration. Regen Med. 2010;5(1):121-43. https://doi.org/10.2217/rme.09. 74.

8. Kusuma GD, Carthew J, Lim R, Frith JE. Effect of the microenvironment on mesenchymal stem cell paracrine signaling: opportunities to engineer the therapeutic effect. Stem Cells Dev. 2017;26(9):617-31. https://doi.org/10.1 089/scd.2016.0349

9. Giuliani N, Lisignoli G, Magnani M, Racano C, Bolzoni M, Dalla Palma B, et al. New insights into osteogenic and chondrogenic differentiation of human bone marrow mesenchymal stem cells and their potential clinical applications for bone regeneration in pediatric orthopaedics. Stem Cells Int. 2013;2013:1-11. https://doi.org/10.1155/2013/312501. 
10. Veneruso V, Rossi F, Villella A, Bena A, Forloni G, Veglianese P. Stem cell paracrine effect and delivery strategies for spinal cord injury regeneration. J Control Release. 2019;300:141-53. https://doi.org/10.1016/j.jconrel.2019.02.03 8.

11. Azzopardi J, Blundell R. Umbilical cord stem cells. Stem Cell Discov. 2018; 8(01):1-11. https://doi.org/10.4236/scd.2018.81001.

12. Gluckman E, Broxmeyer HE, Auerbach AD. Hematopoietic reconstitution in a patient with Fanconi's anemia by means of umbilical cord blood from an HLA-identical sibling. N Engl J Med. 1989;321(17):1174-8. https://doi.org/1 0.1056/NEJM198910263211707.

13. Riordan NH, Morales I, Fernández G, Allen N, Fearnot NE, Leckrone ME, et al. Clinical feasibility of umbilical cord tissue-derived mesenchymal stem cells in the treatment of multiple sclerosis. J Transl Med. 2018;16(1):57. https:// doi.org/10.1186/s12967-018-1433-7.

14. Bartolucci J, Verdugo FJ, González PL, Larrea RE, Abarzua E, Goset C, et al. Safety and efficacy of the intravenous infusion of umbilical cord mesenchymal stem cells in patients with heart failure: a phase 1/2 randomized controlled trial (RIMECARD trial [randomized clinical trial of intravenous infusion umbilical cord mesenchymal stem cells on cardiopathy]). Circ Res. 2017;121(10):1192-204. https://doi.org/10.1161/ CIRCRESAHA.117.310712.

15. Meng F, Xu R, Wang S, Xu Z, Zhang C, Li Y, et al. Human umbilical cordderived mesenchymal stem cell therapy in patients with COVID-19: a phase 1 clinical trial. Signal Transduct Target Ther. 2020;5(1):172. https://doi.org/1 0.1038/s41392-020-00286-5.

16. Rosenbaum P. A report: the definition and classification of cerebral palsy. Dev Med Child Neurol. 2007;49(6):480.

17. Toyokawa S, Maeda E, Kobayashi Y. Estimation of the number of children with cerebral palsy using nationwide health insurance claims data in Japan. Dev Med Child Neurol. 2017:59(3):317-21. https://doi.org/10.1111/dmcn.13278.

18. Zhang J, Yang C, Chen J, Luo M, Qu Y, Mu D, et al. Umbilical cord mesenchymal stem cells and umbilical cord blood mononuclear cells improve neonatal rat memory after hypoxia-ischemia. Behav Brain Res. 2019;362:56-63. https://doi.org/10.1016/j.bbr.2019.01.012.

19. Serrenho I, Rosado M, Dinis A, MCardoso C, Grãos M, Manadas B, et al. Stem cell therapy for neonatal hypoxic-ischemic encephalopathy: a systematic review of preclinical studies. Int J Mol Sci. 2021;22(6):3142.

20. Phillips AW, Johnston MV, Fatemi $\mathrm{A}$. The potential for cell-based therapy in perinatal brain injuries. Transl Stroke Res. 2013;4(2):137-48. https://doi.org/1 0.1007/s12975-013-0254-5.

21. Novak I, Walker K, Hunt RW, Wallace EM, Fahey M, Badawi N. Concise review: Stem cell interventions for people with cerebral palsy: systematic review with meta-analysis. Stem Cells Transl Med. 2016;5(8):1014-25. https:// doi.org/10.5966/sctm.2015-0372.

22. Jantzie LL, Scafidi J, Robinson S. Stem cells and cell-based therapies for cerebral palsy: a call for rigor. Pediatr Res. 2018;83(1):345-55. https://doi. org/10.1038/pr.2017.233

23. Eggenberger S, Boucard C, Schoeberlein A, Guzman R, Limacher A, Surbek $D$, et al. Stem cell treatment and cerebral palsy: systemic review and metaanalysis. World J Stem Cells. 2019;11(10):891-903. https://doi.org/10.4252/ wjsc.v11.i10.891.

24. Bobath K, Bobath B. The neurodevelopmental treatment. In: Scrutton D, editor. Management of the motor disorders of children with cerebral palsy. Oxford: Blackwell Scientific Publications Ltd; 1984. p. 6-18.

25. Knox V, Evans AL. Evaluation of the functional effects of a course of Bobath therapy in children with cerebral palsy: a preliminary study. Dev Med Child Neurol. 2002 Jul:44(7):447-60. https://doi.org/10.1017/s0012162201002353.

26. Palisano R, Rosenbaum P, Walter S, Russell D, Wood E, Galuppi B. Development and reliability of a system to classify gross motor function in children with cerebral palsy. Dev Med Child Neurol. 1997; 39(4):214-23. https://doi.org/10.1111/j.1469-8749.1997.tb07414.x

27. Rosenbaum PL, Palisano RJ, Bartlett DJ, Galuppi BE, Russell DJ. Development of the gross motor function classification system for cerebral palsy. Dev Med Child Neurol. 2008;50(4):249-53. https://doi.org/10.1111/j.1469-8749.2 008.02045.x

28. Becher JG, Pangalila RF, Vermeulen RJ, Barneveld TA, Raats CJ. Richtlijn diagnostiek en behandeling van kinderen met spastische Cerebrale Parese. Utrecht: Nederlandse Vereniging van Revalidatieartse; 2006.

29. Russell DJ, Rosenbaum PL, Wright M, Avery LM. Gross motor function measure (GMFM-66 \& GMFM-88) User's Manual. London: Mac Keith Press; 2013
30. Salehi R, Keshavarz A, Negahban H, Saeedi A, Shiravi A, Ghorbani S, et al. Development of the Persian version of gross motor function measure-88 (GMFM-88): A study of reliability. Trends Med Res. 2015; 10(3):69-74.

31. Gracies JM. Pathophysiology of spastic paresis. I: paresis and soft tissue changes. Muscle Nerve. 2005;31(5):535-51. https://doi.org/10.1002/mus.2 0284

32. Charalambous CP. Interrater reliability of a modified Ashworth scale of muscle spasticity. In: Classic papers in orthopaedics. London: Springer; 2014. p. 415-7.

33. Fosang AL, Galea MP, McCoy AT, Reddihough DS, Story I. Measures of muscle and joint performance in the lower limb of children with cerebral palsy. Dev Med Child Neurol. 2003;45(10):664-70. https://doi.org/10.1017/ s0012162203001245.

34. Clopton N, Dutton J, Featherston T, Grigsby A, Mobley J, Melvin J. Interrater and intrarater reliability of the Modified Ashworth Scale in children with hypertonia. Pediatr Phys Ther. 2005;17(4):268-74. https://doi.org/10.1097/01. pep.0000186509.41238.1a.

35. Ansari NN, Naghdi S, Arab TK, Jalaie S. The interrater and intrarater reliability of the Modified Ashworth Scale in the assessment of muscle spasticity: limb and muscle group effect. NeuroRehabilitation. 2008;23(3):231-7. https://doi. org/10.3233/NRE-2008-23304.

36. Moradi Abbasabadi M, Akbarfahimi N, Hosseini SA, Rezasoltani P. Reliability of the Persian version of the pediatric evaluation of disability inventory in 3 to 9-year old children with cerebral palsy. J Mazandaran Univ Med Sci. 2015; 25(130):129-37.

37. Soleimani F, Vameghi R, Kazemnejad A, Fahimi NA, Nobakht Z, Rassafiani M. Psychometric properties of the persian version of cerebral palsy quality of life questionnaire for children. Iran J Child Neurol. 2015: 9(1):76-86.

38. Leemans A, Jeurissen B, Sijbers J, Jones DK. ExploreDTI: a graphical toolbox for processing, analyzing, and visualizing diffusion MR data. Hawaii, USA: 17th Annual Meeting of Intl Soc Mag Reson Med; 2009. p. 3537.

39. Liang KY, Zeger SL. Longitudinal data analysis using generalized linear models. Biometrika. 1986;73(1):13-22. https://doi.org/10.1093/biomet/73.1.13.

40. Wang $X, H u H$, Hua $R$, Yang J, Zheng $P$, Niu $X$, et al. Effect of umbilical cord mesenchymal stromal cells on motor functions of identical twins with cerebral palsy: pilot study on the correlation of efficacy and hereditary factors. Cytotherapy. 2015;17(2):224-31. https://doi.org/10.101 6/j.jcyt.2014.09.010

41. Liu X, Fu X, Dai G, Wang X, Zhang Z, Cheng H, et al. Comparative analysis of curative effect of bone marrow mesenchymal stem cell and bone marrow mononuclear cell transplantation for spastic cerebral palsy. J Transl Med. 2017;15(1):48. https://doi.org/10.1186/s12967-017-114 9-0.

42. Chen $G$, Wang $Y, X u$ Z, Fang F, Xu R, Wang $Y$, et al. Neural stem cell-like cells derived from autologous bone mesenchymal stem cells for the treatment of patients with cerebral palsy. J Transl Med. 2013;11(1):21. https://doi.org/10.1186/1479-5876-11-21.

43. Gu J, Huang L, Zhang C, Wang Y, Zhang R, Tu Z, et al. Therapeutic evidence of umbilical cord-derived mesenchymal stem cell transplantation for cerebral palsy: a randomized, controlled trial. Stem Cell Res Ther. 2020;11(1): 43. https://doi.org/10.1186/s13287-019-1545-x.

44. Rosenbaum PL, Walter SD, Hanna SE, Palisano RJ, Russell DJ, Raina P, et al. Prognosis for gross motor function in cerebral palsy: creation of motor development curves. JAMA. 2002;288(11):1357-63. https://doi.org/10.1001/ja ma.288.11.1357.

45. Sharma A, Sane H, Gokulchandran N, Kulkarni P, Gandhi S, Sundaram J, et al. A clinical study of autologous bone marrow mononuclear cells for cerebral palsy patients: a new frontier. Stem Cells Int. 2015;2015:905874

46. Zali A, Arab L, Ashrafi F, Mardpour S, Niknejhadi M, Hedayati-Asl AA, et al. Intrathecal injection of CD133-positive enriched bone marrow progenitor cells in children with cerebral palsy: feasibility and safety. Cytotherapy. 2015; 17(2):232-41. https://doi.org/10.1016/j.jcyt.2014.10.011.

47. Wang X, Cheng H, Hua R, Yang J, Dai G, Zhang Z, et al. Effects of bone marrow mesenchymal stromal cells on gross motor function measure scores of children with cerebral palsy: a preliminary clinical study. Cytotherapy. 2013;15(12):1549-62. https://doi.org/10.1016/j.jcyt.2013.06.001.

48. Shroff G, Gupta A, Barthakur JK. Therapeutic potential of human embryonic stem cell transplantation in patients with cerebral palsy. J Transl Med. 2014; 12(1):318. https://doi.org/10.1186/s12967-014-0318-7. 
49. Findikli N, Candan NZ, Kahraman S. Human embryonic stem cell culture: current limitations and novel strategies. Reprod Biomed Online. 2006;13(4): 581-90. https://doi.org/10.1016/S1472-6483(10)60648-7.

50. Luan Z, Liu W, Qu S, du K, He S, Wang Z, et al. Effects of neuroprogenitor cells transplantation in severe cerebral palsy. Cell Transplant. 2012;21(1_ suppl):91-8. https://doi.org/10.3727/096368912X633806.

51. Chen L, Huang H, Xi H, Xie Z, Liu R, Jiang Z, et al. Intracranial transplant of olfactory ensheathing cells in children and adolescents with cerebral palsy: a randomized controlled clinical trial. Cell Transplant. 2010;19(2):185-91. https://doi.org/10.3727/096368910X492652.

52. Huang L, Zhang C, Gu J, Wu W, Shen Z, Zhou X, et al. A randomized, placebo-controlled trial of human umbilical cord blood mesenchymal stem cell infusion for children with cerebral palsy. Cell Transplant. 2018;27(2):32534. https://doi.org/10.1177/0963689717729379.

53. Kang M, Min K, Jang J, Kim SC, Kang MS, Jang SJ, et al. Involvement of immune responses in the efficacy of cord blood cell therapy for cerebral palsy. Stem Cells Dev. 2015;24(19):2259-68. https://doi.org/10.1 089/scd.2015.0074.

54. Min K, Song J, Kang JY, Ko J, Ryu JS, Kang MS, et al. Umbilical cord blood therapy potentiated with erythropoietin for children with cerebral palsy: a double-blind, randomized, placebo-controlled trial. Stem Cells. 2013;31(3): 581-91. https://doi.org/10.1002/stem.1304.

55. Li Y, Chen J, Wang L, Lu M, Chopp M. Treatment of stroke in rat with intracarotid administration of marrow stromal cells. Neurology. 2001;56(12): 1666-7. https://doi.org/10.1212/WNL.56.12.1666.

56. Rodríguez-Frutos B, Otero-Ortega L, Gutiérrez-Fernández M, Fuentes B, Ramos-Cejudo J, Díez-Tejedor E. Stem cell therapy and administration routes after stroke. Transl Stroke Res. 2016;7(5):378-87. https://doi.org/10.1 007/s12975-016-0482-6.

57. Walczak P, Zhang J, Gilad AA, Kedziorek DA, Ruiz-Cabello J, Young RG, et al. Dual-modality monitoring of targeted intraarterial delivery of mesenchymal stem cells after transient ischemia. Stroke. 2008;39(5):1569-74. https://doi. org/10.1161/STROKEAHA.107.502047.

58. Dong H, Li G, Shang C, Yin H, Luo Y, Meng H, et al. Umbilical cord mesenchymal stem cell (UC-MSC) transplantations for cerebral palsy. Am J Transl Res. 2018;10(3):901-6.

59. Feng J, Offerman E, Lin J, Fisher E, Planchon SM, Sakaie K, et al. Exploratory MRI measures after intravenous autologous culture-expanded mesenchymal stem cell transplantation in multiple sclerosis. Mult Scler J Exp Transl Clin. 2019:5(2):2055217319856035.

60. Chen YY, Zhang X, Lin XF, Zhang F, Duan XH, Zheng CS, et al. DTI metrics can be used as biomarkers to determine the therapeutic effect of stem cells in acute peripheral nerve injury. J Magn Reson Imaging. 2017;45(3):855-62. https://doi.org/10.1002/jmri.25395.

61. Jirjis MB, Valdez C, Vedantam A, Schmit BD, Kurpad SN. Diffusion tensor imaging as a biomarker for assessing neuronal stem cell treatments affecting areas distal to the site of spinal cord injury. J Neurosurg Spine. 2017;26(2):243-51. https://doi.org/10.3171/2016.5.SPINE151319.

62. Yoshida S, Hayakawa K, Yamamoto A, Okano S, Kanda T, Yamori Y, et al. Quantitative diffusion tensor tractography of the motor and sensory tract in children with cerebral palsy. Dev Med Child Neurol. 2010;52(10):935-40. https://doi.org/10.1111/j.1469-8749.2010.03669.x.

63. Thomas B, Eyssen M, Peeters $R$, Molenaers $G$, Van Hecke $P$, De Cock $P$, et al. Quantitative diffusion tensor imaging in cerebral palsy due to periventricular white matter injury. Brain. 2005;128(11):2562-77. https://doi. org/10.1093/brain/awh600.

64. Jiang H, Li X, Jin C, Wang M, Liu C, Chan KC, et al. Early diagnosis of spastic cerebral palsy in infants with periventricular white matter injury using diffusion tensor imaging. Am J Neuroradiol. 2019;40(1):162-8. https://doi. org/10.3174/ajnr.A5914.

65. Wang S, Fan GG, Xu K, Wang C. Altered microstructural connectivity of the superior and middle cerebellar peduncles are related to motor dysfunction in children with diffuse periventricular leucomalacia born preterm: a DTI tractography study. Eur J Radiol. 2014;83(6):997-1004. https://doi.org/10.101 6/j.ejrad.2014.03.010.

66. Scheck SM, Boyd RN, Rose SE. New insights into the pathology of white matter tracts in cerebral palsy from diffusion magnetic resonance imaging: a systematic review. Dev Med Child Neurol. 2012;54(8):684-96. https://doi. org/10.1111/j.1469-8749.2012.04332.x.

67. Trivedi R, Gupta RK, Shah V, Tripathi M, Rathore RK, Kumar M, et al. Treatment-induced plasticity in cerebral palsy: a diffusion tensor imaging study. Pediatr Neurol. 2008;39(5):341-9. https://doi.org/10.1016/j.pedia trneurol.2008.07.012.

68. Jiang H, Liu H, He H, Yang J, Liu Z, Huang T, et al. Specific white matter lesions related to motor dysfunction in spastic cerebral palsy: a metaanalysis of diffusion tensor imaging studies. J Child Neurol. 2020;35(2):14654. https://doi.org/10.1177/0883073819879844

69. Arrigoni F, Peruzzo D, Gagliardi C, Maghini C, Colombo P, lammarrone FS, et al. Whole-brain DTI assessment of white matter damage in children with bilateral cerebral palsy: evidence of involvement beyond the primary target of the anoxic insult. Am J Neuroradiol. 2016;37(7):1347-53. https://doi.org/1 0.3174/ajnr.A4717.

\section{Publisher's Note}

Springer Nature remains neutral with regard to jurisdictional claims in published maps and institutional affiliations.
Ready to submit your research? Choose BMC and benefit from:

- fast, convenient online submission

- thorough peer review by experienced researchers in your field

- rapid publication on acceptance

- support for research data, including large and complex data types

- gold Open Access which fosters wider collaboration and increased citations

- maximum visibility for your research: over $100 \mathrm{M}$ website views per year

At BMC, research is always in progress.

Learn more biomedcentral.com/submissions 